\title{
NOWOCZESNE MATERIALY STOSOWANE W KONSTRUKCJACH LOTNICZYCH - WYBRANE PROBLEMY ORAZ KIERUNKI ROZWOJU
}

\begin{abstract}
W artykule dokonano analizy materiałów stosowanych we współczesnych konstrukcjach lotniczych, skupiając uwagę na strukturze płatowca samolotu. Przedstawiono wybrane problemy dotyczące projektowania i eksploatacji struktur lotniczych, z uwzględnieniem kompozytów oraz metali lekkich (aluminium, tytan i ich stopy). Omówiono problemy obróbki mechanicznej, takiej jak: szlifowanie, wykonywanie otworów itp. Przedstawiono problemy analizy metodą elementów skończonych (MES), na podstawie dwóch próbek wykonanych ze stopu aluminium oraz z włóknistego kompozytu szklanego. Zaprezentowano różnice w budowie oraz modelowaniu tych materiałów, wynikające $\mathrm{z}$ ich różnorakiej struktury (izotropia i anizotropia). Dokonano analizy mechaniki niszczenia metalu, porównując go z kompozytem. Przedstawiono tendencje oraz kierunki rozwoju lotniczych materiałów konstrukcyjnych z uwzględnieniem materiałów metalowo-kompozytowych. Przedmiotem niniejszego artykułu są współczesne materiały konstrukcyjne wykorzystywane w strukturach lotniczych. Celem publikacji jest porównanie współczesnych materiałów konstrukcyjnych (kompozytów oraz metali) oraz przedstawienie wybranych problemów w ich projektowaniu, konstruowaniu oraz eksploatacji. Tezy, uzasadnione wynikami analizy symulacji oraz badań, zostały przedstawione w treści i podsumowaniu artykułu.
\end{abstract}

Słowa kluczowe: konstrukcje lotnicze, kompozyty, metale lekkie, metoda elementów skończonych (MES)

\footnotetext{
${ }^{1}$ Autor do korespondencji/corresponding author: Radosław Bielawski, Akademia Obrony Narodowej, ul. Chruściela 103, 00-910 Warszawa, tel.: (22) 6813243, e-mail: r.bielawski@aon.edu.pl.

${ }^{2}$ Witold Rządkowski, Politechnika Warszawska, e-mail: wrzadkowski@meil.pw.edu.pl.

${ }^{3}$ Sławomir Augustyn, Akademia Obrony Narodowej, e-mail: s.augustyn@aon.edu.pl.

${ }^{4}$ Paweł Pyrzanowski, Politechnika Warszawska, e-mail: pyrzan@meil.pw.edu.pl.
} 


\section{Wstęp}

Zmiany w lotnictwie następują bardzo szybko. Dynamicznej modyfikacji ulega nie tylko sposób konstruowania samolotów - zmieniają się również używane materiały. Zauważalna jest tendencja do stosowania tych bardzo lekkich, które zarazem posiadają bardzo dobre właściwości mechaniczne. Tym samym dąży się do obniżania masy statków powietrznych przy zachowaniu ich gabarytów. Pozwala to na zwiększenie transportowanego ładunku, zasięgu czy też zmniejszenie emisji dwutlenku węgla i innych substancji szkodliwych dla atmosfery.

W pierwszych konstrukcjach lotniczych do budowy płatowców stosowano drewno i stal, a do poszycia płótno, skórę czy papier. Następnym krokiem w wykorzystaniu materiałów do budowy struktur nośnych było użycie blachy stalowej oraz aluminiowej. Najpierw kryto nią spodnią, a następnie wierzchnią powierzchnię skrzydeł. W drugiej połowie lat 40. XX w. nastąpiła dynamiczna zmiana myśli konstrukcyjnej. Stal stosowano w konstrukcji wytrzymałościowej skrzydeł oraz w ich poszyciach. Kompozyty oraz stopy tytanu zaczęto stosować w latach 50. i 60. ubiegłego wieku, natomiast radykalne zmiany w wykorzystaniu tych materiałów dokonały się w latach 80 . Zaczęto używać wysoko zaawansowanych hybrydowych kompozytów na bazie aluminium i tytanu. Obecnie jednym z najczęściej stosowanych materiałów są laminaty o włóknach szklanych lub węglowych, z których płatowce niektórych współczesnych samolotów są wykonane niemal w całości. Innym wszechstronnie używanym włóknem jest aramid. Stanowi on często dodatkowe poszycie w samolotach i śmigłowcach lotnictwa wojskowego. Jego wytrzymałość mechaniczna pozwala na ochronę załogi nawet przed skutkami trafienia głowicami pocisków przeciwpancernych i odłamkowo-burzących kalibru $23 \mathrm{~mm}$. Obecnie zauważalny jest wzrost stosowania aluminium oraz jego stopów, które stanowią konkurencję dla materiałów kompozytowych. Kolejnym wykorzystywanym metalem jest tytan. Posiada bardzo korzystne właściwości mechaniczne oraz mechaniczno-termiczne. Jego wytrzymałość na rozciąganie jest dwukrotnie większa niż stali przy tej samej masie. Współczesne materiały, technologia wytwarzania oraz programy wsparcia projektowania pozwalają budować statki powietrzne o takich właściwościach, o których jeszcze kilka lat temu trudno było myśleć, przy zachowaniu ich gabarytów, wytrzymałości oraz żywotności i ciągłej redukcji masy.

\section{Metale i ich stopy w konstrukcjach lotniczych}

Metale (stal, aluminium, tytan oraz ich stopy z innymi metalami) są podstawowym materiałem używanym w konstrukcjach lotniczych. Jeszcze w $2000 \mathrm{r}$. udział masowy stali wynosił ok. 8,1\% [6]. Obecnie w konstruowaniu elementów nośnych stal została wyparta przez takie metale, jak tytan oraz aluminium. Nadal 
jest powszechnie używana w elementach konstrukcyjnych silników lotniczych, natomiast $\mathrm{w}$ produkcji elementów nośnych ${ }^{5}$ właściwie nie jest już spotykana.

\section{Aluminium i jego stopy}

Stopy aluminium należą do najważniejszych materiałów konstrukcyjnych stosowanych w przemyśle lotniczym. Główne składniki stopów aluminium w lotnictwie to: miedź, krzem, mangan, magnez i cynk. Dodatkami w ilościach małoprocentowych są: nikiel, żelazo, tytan, chrom, beryl i in. Ze stopów aluminium wykonuje się bardzo obciążone elementy konstrukcji lotniczych, takie jak dźwigary, użebrowania, poszycia, wsporniki konstrukcji płatów [15]. Ważnym elementem w projektowaniu skrzydeł samolotów są elementy łączące - nity (nitonakrętki), które także są wykonane $\mathrm{z}$ aluminium.

$\mathrm{Z}$ zastosowaniem aluminium oraz jego stopów wiążą się liczne problemy. Jednym z nich jest łamanie się wiórów przy jego obróbce. Podczas toczenia grube wióry (często o dużej wytrzymałości) owijają się wokół materiału obrabianego lub narzędzia. Zjawisko to można ograniczyć, stosując odpowiednie kąty natarcia, łamacze wiórów oraz fazki z ujemnym kątem natarcia, które poprawiają efektywność procesu [8]. Innym rozwiązaniem jest modyfikacja składu przez dodanie różnych pierwiastków stopowych zwiększających poślizg w strefie tworzenia się wióra.

Kolejnym problemem jest stosowanie w procesie obróbki mechanicznej drogich narzędzi oraz wierteł, których żywotność jest stosunkowo krótka. Koszt obróbki aluminium i jego stopów jest zatem wysoki. Istotna jest również kwestia łączenia aluminium i jego stopów za pomocą złączy spawanych. Główne problemy, jakie występują podczas spawania stopów aluminium, wynikają z dużego powinowactwa aluminium do tlenu i powstawania trudnotopliwego tlenku, wysokiej przewodności cieplnej oraz dużej rozszerzalności. Proces ten utrudniają duże spadki wytrzymałości w temperaturach spawania oraz utrata pierwiastków stopowych, takich jak magnez, cynk czy lit [1]. Spawanie aluminium odbywa się przeważnie w otoczeniu gazu ochronnego (argon, hel z argonem i in.), co znacznie zwiększa koszty tego procesu.

\section{Tytan i jego stopy}

Tytan to pierwiastek metaliczny znany ze swojej wysokiej wytrzymałości mechanicznej w stosunku do ciężaru właściwego. Jest metalem bardzo lekkim (gęstość $4507 \mathrm{~kg} / \mathrm{m}^{3}$ ). Charakteryzuje się wysoką temperaturą topnienia, wynoszącą $1668^{\circ} \mathrm{C}$. Handlowy tytan o czystości $99,2 \%$ jest lżejszy od stali o ok. $45 \%$, a cięższy od aluminium o 60\% [10]. Posiada bardzo dobre właściwości chemiczne. Jego najbardziej charakterystyczną cechą jest doskonała odporność na

\footnotetext{
${ }^{5}$ Elementy nośne to elementy konstrukcyjne samolotu wytwarzające siłę nośną - skrzydła samolotu.
} 
korozję, porównywalna do odporności platyny. Należy do grupy paramagnetyków, wykazując niską przewodność cieplną oraz elektryczną. Dzięki swoim właściwościom z powodzeniem znalazł zastosowanie w lotnictwie oraz przemyśle kosmicznym. Wykorzystywanie tytanu wprowadziło nowe jakościowo konstrukcje lotnicze, czyli nowoczesne silniki i płatowce o znacznie zmniejszonej masie konstrukcji. Pozwoliło to zwiększyć osiągi budowanych samolotów. W nowoczesnych konstrukcjach płatowca $\mathrm{z}$ tytanu wykonuje się: elementy siłowe, elementy łączące (nity, śruby, sworznie itp.) oraz konstrukcje nośne skrzydeł. Udział wagowy tytanu w tworzeniu płatowców w latach 80 . minionego stulecia ustabilizował się na poziomie 7-12\% [6]. W najnowocześniejszych produktach firmy Boeing (787 Dreamliner) oraz Airbus (model A380) jego udział wynosi $15 \%$.

$\mathrm{Z}$ tytanem i jego zastosowaniem łączą się liczne problemy. Sam proces wytwarzania tytanu jest obarczony wieloma niedogodnościami. Otrzymuje się go przez redukcję dwutlenku tytanu. Stosowana metoda Krolla jest jednak bardzo kosztowna. Duży problem stanowi proces topnienia tytanu, ze względu na wytwarzanie się wysokiej temperatury. Poza tym tytan $w$ temperaturze topnienia wykazuje aktywność chemiczną [10]. Kolejnym aspektem jest obróbka mechaniczna tego materiału. Odzysk metalu ze złomu i wiórów jest procesem uciążliwym technologicznie. Często stosuje się techniki bezwiórowe, lecz są one ściśle związane z modyfikacją jego składu, a co za tym idzie - właściwości mechanicznych.

\section{Materiały kompozytowe}

Materiał kompozytowy (krócej kompozyt, laminat) jest to tworzywo złożone z dwóch (lub większej liczby) komponentów o różnych właściwościach [5]. Głównymi składnikami kompozytu są: osnowa (zwana matrycą) oraz wzmocnienie (inaczej zbrojenie). Osnowa stanowi przeważnie 10-80\% objętości całego kompozytu. Jest to jednolity materiał wypełniający przestrzeń między elementami wzmacniającymi, jednocześnie stanowiący dla nich spoinę. Jej dodatkową rolą jest ochrona materiału wzmacniającego, przenoszenie na niego naprężeń zewnętrznych i nadawanie żądanego kształtu wytworzonej części. Wzmocnienie odpowiada za ukształtowanie pozostałych właściwości kompozytu.

Materiały kompozytowe są obecnie stosowane bardzo powszechnie. W porównaniu z metalami mają wysoką sztywność oraz wytrzymałość mechaniczną przy stosunkowo małej masie. W przemyśle lotniczym najczęściej używaną grupą są kompozyty włókniste, których zbrojenie jest zbudowane z włókien. Są one elementem nośnym, natomiast matryca służy jako spoiwo łączące włókna i zapewnia rozdział obciążenia zewnętrznego pomiędzy włókna. Chroni je także przed czynnikami zewnętrznymi [3]. Najbardziej rozpowszechnionymi rodzajami wzmocnienia stosowanymi w kompozytach włóknistych są włókna: szklane G (Glass), węglowe C (Carbon) oraz aramidowe A (Aramid). Kompozyty włók- 
niste są najbardziej efektywnymi spośród materiałów kompozytowych, ponieważ wykazują najlepsze właściwości mechaniczne i wytrzymałościowe przy najmniejszym ciężarze właściwym. Ich jedyną wadą jest wyższa cena [2]. We współczesnych konstrukcjach lotniczych wykorzystuje się najczęściej kompozyty wzmacniane włóknami szklanymi GFRP $^{6}$ oraz włóknami węglowymi CFRP $^{7}[13]$.

Przykładem znaczącego zmniejszenia masy samolotu dzięki zastosowaniu materiałów kompozytowych jest samolot Airbus A380. Około 22\% struktury podstawowej samolotu (w stosunku wagowym) wykonano z różnych kompozytów włóknistych $\mathrm{z}$ osnową z żywicy epoksydowej. Powodem była wysoka sztywność wzmacniających włókien węglowych, o wartości $935 \mathrm{GPa}$ (70 GPa dla stopów aluminium) [11]. Airbus wykorzystuje w swoich produktach również kompozyty GFRP. Znalazły one zastosowanie w usterzeniu pionowym wielu współczesnych samolotów tej firmy. Nowo stosowanym kompozytem w konstrukcjach współczesnego lotnictwa jest GLARE (Glass Fibre Reinforced Aluminium Laminates). Stanowi on rozwiązanie hybrydowe złożone z 2-6 warstw aluminium o grubości od 0,2 do $0,5 \mathrm{~mm}$. Pomiędzy skrajnymi warstwami aluminium są usytuowane na przemian warstwy włókien i metalu. Powłoki ukierunkowanych włókien szklanych o grubości 0,125-0,500 mm są spojone osnową z żywicy epoksydowej i połączone z aluminium. Materiał typu GLARE jest droższy od aluminium i innych kompozytów. Ma niską gęstość i jest odporniejszy na korozję. Jego niewątpliwą zaletę stanowi odporność na pęknięcia, a dodatkowo warstwowa, metalowo-kompozytowa konstrukcja zapobiega propagacji w miejscu jego powstania.

Kolejnym przykładem zastosowania zaawansowanych materiałów kompozytowych w lotnictwie jest Boeing 787 Dreamliner. W samolocie tym udział masowy kompozytów wynosi ok. 50\%, natomiast udział objętościowy $-80 \%$. $\mathrm{W}$ większości są to laminaty wzmacniane włóknem węglowym. Zostały zastosowane w skrzydłach, kadłubie oraz usterzeniu tego samolotu. Szacuje się, że dalsza przyszłość lotnictwa będzie związana z zastosowaniem tego typu kompozytu.

Kompozyty są materiałami trudnymi w obróbce mechanicznej. Problemy wiążą się $\mathrm{z}$ doborem odpowiednich narzędzi skrawających, zużywaniem się ostrzy narzędzi skrawających, możliwościami obróbki skomplikowanych powierzchni krzywoliniowych, jak również z obróbką w miejscach trudno dostępnych. Wiele problemów koncentruje się wokół efektu delaminacji ${ }^{8}$ zachodzącego podczas oddziaływań narzędzia skrawającego na materiał przedmiotu obrabianego. Następną niedogodność stanowi dobór odpowiednich urządzeń odpylających, odprowadzających pyły szkodliwe zarówno dla zdrowia, jak i maszyny.

\footnotetext{
${ }^{6}$ GFRP - Glass Fiber Reinforced Plastics.

${ }^{7}$ CFRP - Carbon Fiber Reinforced Plastics.

${ }^{8}$ Termin został wyjaśniony w dalszej części artykułu.
} 
Wiele problemów wiąże się z przetwarzaniem warstwy skrawanej w wiór oraz zachowaniem wymagań dotyczących stanu geometrycznego powierzchni po obróbce. Typowymi sposobami obróbki skrawaniem kompozytów jest frezowanie, wiercenie i cięcie. Coraz powszechniejszymi technikami obróbki kompozytów są także cięcie wysokociśnieniową strugą wodno-ścierną ${ }^{9}$ [7] oraz obróbka laserowa.

\section{Problemy w modelowaniu}

Metoda elementów skończonych - MES jest obecnie najszerzej stosowaną metodą obliczeniową, mającą zastosowanie w niemal wszystkich typach zadań inżynierskich. Analiza konstrukcji metodą elementów skończonych polega na zamianie pełnej konstrukcji, dla której nie można analitycznie znaleźć rozkładu naprężeń, na bardzo dużą liczbę niewielkich, powiązanych ze sobą elementów, dla których istnieją proste rozwiązania analityczne. $\mathrm{Z}$ uwagi na bardzo dużą liczbę powstałych równań rozwiązuje się je najczęściej numerycznie.

Model obliczeniowy powstaje przez podział badanej konstrukcji na elementy skończone (dyskretyzacja). Na tym etapie określa się gęstość siatki w wybranych fragmentach modelu, liczbę węzłów w elemencie (elementy z większą liczbą węzłów mogą być opisane funkcjami wyższego rzędu), rodzaj materiału i jego właściwości oraz warunki brzegowe. Konstrukcje są na ogół obiektami trójwymiarowymi, lecz z uwagi na wykorzystanie różnego rodzaju symetrii, płaskich stanów odkształceń i naprężeń, wiele modeli można rozważać jako obiekty dwuwymiarowe (powłokowe) lub jednowymiarowe (prętowe). Takie wyidealizowanie badanej konstrukcji pozwala na duże ograniczenie liczby elementów skończonych oraz węzłów. Zmniejsza to liczbę stopni swobody koniecznych do uzyskania zakładanej dokładności obliczeń. Obliczenia, po zdefiniowaniu rodzaju badanego zagadnienia (statyka, przepływy, drgania własne itd.) i określeniu głównych parametrów analizy (stopień szczegółowości wyników, kryterium zbieżności, metoda rozwiązywania), odbywają się bez czynnego udziału użytkownika. Wybrane wyniki można prezentować w postaci map warstwicowych, wykresów, animacji oraz przez zapisanie interesujących użytkownika wartości dla wybranych węzłów. Należy pamiętać, że MES jest metodą przybliżoną, a uzyskane wyniki mogą być obarczone błędem, zależnym od wielu czynników. Każdy uzyskany z MES wynik powinien być wstępnie sprawdzony przez obliczenia analityczne uproszczonych modeli oraz zweryfikowany pod kątem fizycznej poprawności i zgodności z narzuconymi warunkami brzegowymi [16].

Model pokazany w części obliczeniowej został wykonany z elementów powłokowych. W programie ANSYS 15.0 ustalono następujące parametry: grubość powłoki, liczbę warstw oraz orientację w przestrzeni.

\footnotetext{
${ }^{9}$ AWJM - Abrasive Water-Jet Machining.
} 


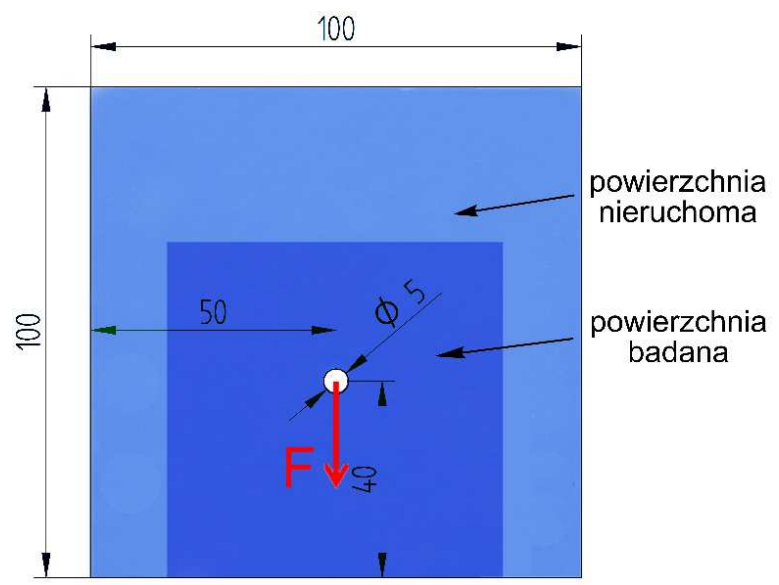

Rys. 1. Wymiary próbki

Fig. 1. Dimensions of the sample

Do badań przyjęto próbki o wymiarach $100 \times 100 \mathrm{~mm}$, o powierzchni badanych przemieszczeń $3600 \mathrm{~mm}^{2}(60 \times 60 \mathrm{~mm})$. W okolicy środka badanej powierzchni wykonano otwór. Zasymulowano siłę o wartości $100 \mathrm{~N}$ działającą w kierunku pionowym (-Y), przyłożoną w środku otworu (rys. 1.), przez dodatkowy element nieodkształcalny o średnicy równej średnicy otworu. Symuluje to obciążenie przykładowo przez nit włożony bez spęczania otworu. W analizie przebadano dwa modele o identycznym kształcie, różniące się modelem materiałowym. Pierwszy model wykonano z jednokierunkowego, 4-warstwowego kompozytu zbrojonego włóknem szklanym o włóknach równoległych do kierunku działania siły, drugi natomiast ze stopu aluminium. Przyjęto dane materiałowe jak w tab. 1. Obie próbki mają jednakową grubość $1 \mathrm{~mm}$, a uzyskane wyniki przemieszczeń w kierunku działania siły pokazano na rys. 2-4.

Tabela 1. Dane materiałowe przyjęte do obliczeń

Table 1 . The material data used in the calculations

\begin{tabular}{|l|c|c|}
\hline \multicolumn{1}{|c|}{ Parametr } & CFRP & Duraluminium \\
\hline Moduł Younga, GPa & $\begin{array}{c}33,4 \\
E_{Y}=E_{Z}=3\end{array}$ & 70 \\
\hline Liczba Poissona & 0,3 & 0,34 \\
\hline Moduł Kirchhoffa, GPa & 4,3 & 26 \\
\hline Gęstość, $\mathrm{kg} / \mathrm{m}^{3}$ & 1900 & 2800 \\
\hline
\end{tabular}


a)

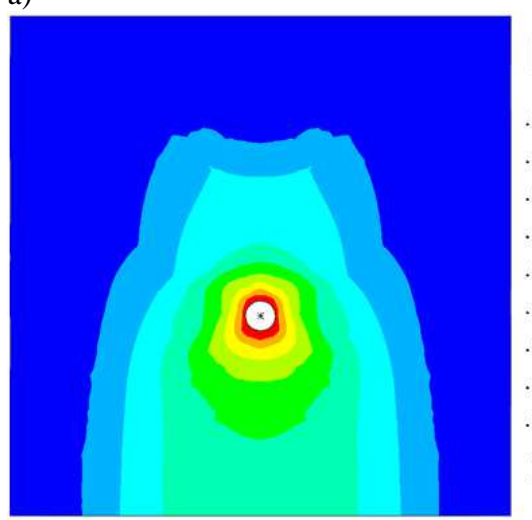

b)

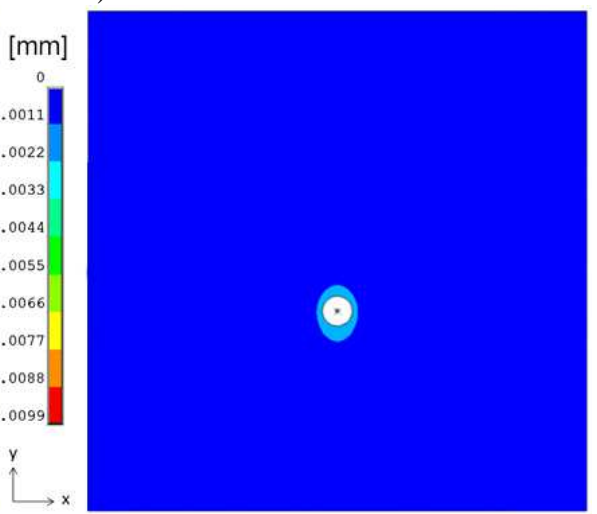

Rys. 2. Mapy przemieszczeń w kierunku działania siły wymuszającej -Y dla próbek o równej grubości $1 \mathrm{~mm}$ : a) z CFRP, b) z duraluminium

Fig. 2. Displacement maps in the force $\mathrm{Y}$ direction $-\mathrm{Y}$ for specimens with the same thickness of $1 \mathrm{~mm}$ : a) CFRP, b) duraluminium

a)

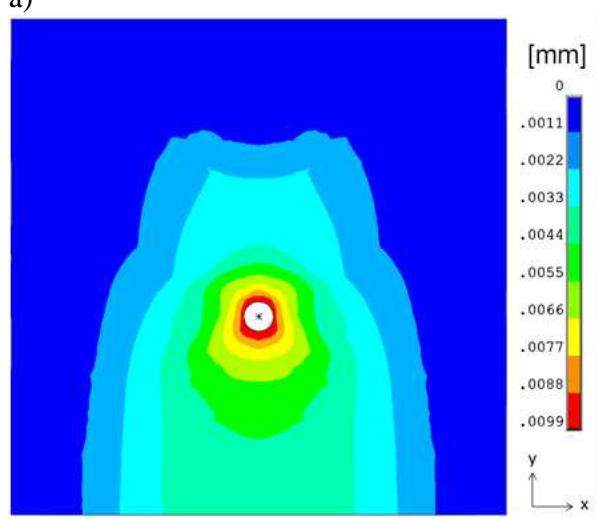

b)

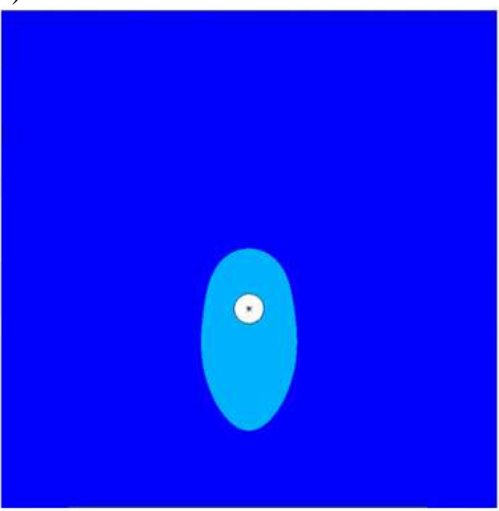

Rys. 3. Mapy przemieszczeń w kierunku działania siły wymuszającej $-Y$, dla próbek o równej masie: a) z CFRP, b) z duraluminium

Fig. 3. Displacement maps in the force $\mathrm{Y}$ direction $-\mathrm{Y}$, for specimens with the same mass: a) CFRP, b) duraluminium

Różnica w wartościach przemieszczeń wynika z ponaddwukrotnie niższego w kompozycie modułu Younga w kierunku wzdłuż włókien -Y, a w szczególności o rząd wielkości niższego modułu Younga w kierunku poprzecznym do osi włókien -X. Materiał izotropowy ma identyczną sztywność w każdym kierunku, natomiast użyty kompozyt w kierunku Y posiada sztywność taką jak materiał zbrojenia. Różnica ta może zostać zniwelowana, pod warunkiem przyjęcia kryterium równych mas, zamiast zastosowania takich samych grubości. Wtedy prób- 
ka o grubości $0,66 \mathrm{~mm}$ wykonana $\mathrm{z}$ duraluminium ulega maksymalnemu przemieszczeniu, większemu o 44\%. Odkształcenia w kompozycie mogą być niższe, jeśli zastosuje się inny układ warstw, np. gdzie obie zewnętrzne powłoki (warstwy) mają kierunek wzdłuż osi X, a środkowe - jak w poprzednich przypadkach - wzdłuż osi Y.

a)

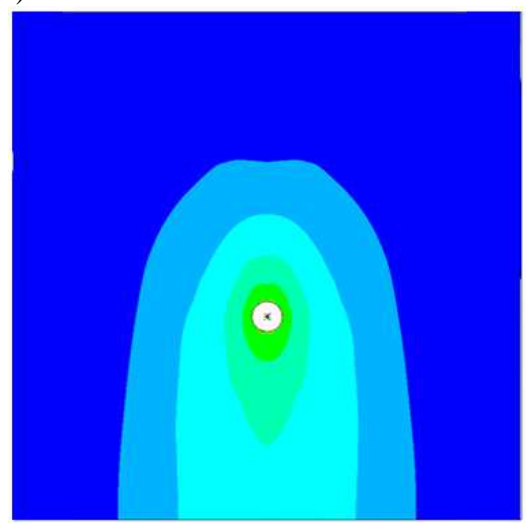

b)

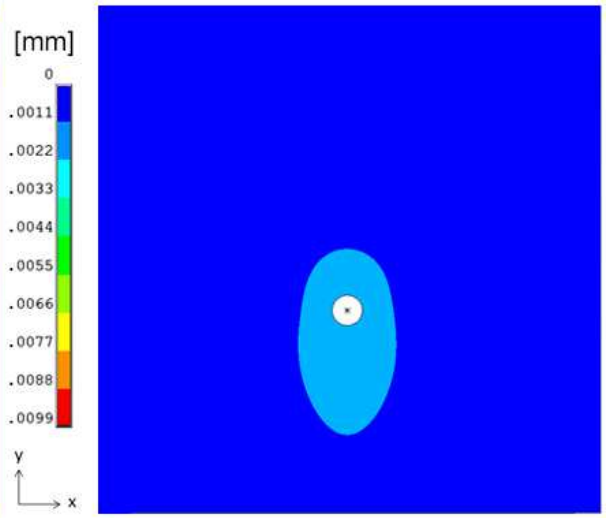

Rys. 4. Mapy przemieszczeń w kierunku działania siły wymuszającej $-Y$, dla próbek o równej masie z CFRP o zmienionym układzie włókien (a) oraz dla wykonanej z duraluminium (b)

Fig. 4. Displacement maps in the force $Y$ direction $-Y$, for specimens with the same mass for the sample made of CFRP with changed fiber orientation (a) and for the sample made of duraluminium (b)

Rezultatem uzyskanych wyników jest wniosek, że istnieją nie tylko trudności ze zidentyfikowaniem właściwości materiałów kompozytowych, ale również $\mathrm{z}$ ich odpowiednim rozmieszczeniem. W takich zadaniach stosuje się metody optymalizacyjne zawarte w programach MES. Układ warstw dobiera się tak, aby był jak najbardziej adekwatny do sposobu obciążenia konstrukcji.

\section{Problemy eksploatacyjne}

Materiały konstrukcyjne zastosowane w strukturach samolotu sa podczas eksploatacji narażone na niesprawności ${ }^{10} \mathrm{i}$ uszkodzenia ${ }^{11}$. Ich występowanie jest uzależnione od użytych materiałów. Zachodzą one przez różnego rodzaju zjawiska fizyczne i chemiczne, m.in. destrukcyjne czynniki mechaniczno-chemiczne,

${ }^{10}$ Niesprawność to takie zdarzenie niepożądane, które pojawia się w systemie technicznym (statek powietrzny), antropotechnicznym (człowiek - statek powietrzny) lub socjotechnicznym (człowiek - statek powietrzny - otoczenie), uniemożliwiając fizyczne lub umowne spełnienie przewidzianych funkcji.

${ }^{11}$ Uszkodzenie to utrata fizycznych właściwości i(lub) właściwości elementu konstrukcyjnego lub przejście struktury technicznej ze stanu zdatności do stanu niezdatności [9]. 
które wywołują różne siły statyczne i dynamiczne działające na konstrukcję, a tym samym na materiał. Są to najczęściej: udary, hałas, wibracje, czyli drgania. Innymi postaciami uszkodzeń są korozja oraz kawitacja. W zależności od zastosowanego materiału przyjmuje on różne formy oraz różny stopień uszkodzenia.

Metalowe części konstrukcji samolotów są narażone na korozję. Jest to zjawisko niszczenia materiału pod wpływem chemicznego lub elektrochemicznego oddziaływania środowiska. W konstrukcjach lotniczych wyróżnia się trzy rodzaje korozji: wżerową, międzykrystaliczną i naprężeniową. Korozja wżerowa niszczy powierzchnię i objętość elementu, natomiast międzykrystaliczna rozprzestrzenia się wzdłuż granic ziaren metali i nie jest widoczna. Ujawnia się dopiero poprzez pogorszenie właściwości mechanicznych materiału [9]. W konstrukcjach lotniczych ten typ korozji jest bardzo niebezpieczny. Zachodzi wyjątkowo szybko, głęboko niszcząc materiał. Jest trudny do wykrycia podczas codziennej obsługi wzrokowej. Korozja naprężeniowa pojawia się wówczas, gdy zachodzi oddziaływanie środowiska korozyjnego oraz naprężeń rozciągających. Dla konstrukcji lotniczych jest ona niebezpieczna. Rozwija się dosyć szybko, tworząc mikroszczeliny. Często uszkodzenie elementu następuje bez przyłożenia obciążenia, jedynie pod wpływem naprężeń własnych. Korozja elementów konstrukcji przyczynia się do obniżenia jej żywotności. To niekorzystne zjawisko dotyczy głównie konstrukcji metalowych. Obecnie są prowadzone prace nad stopami aluminium oraz tytanu, które przeciwdziałają temu zjawisku. Całkowite wyeliminowanie korozji z metalowych konstrukcji lotniczych najprawdopodobniej nie jest jednak możliwe. Kompozyty pod wpływem obciążeń przybierają inne formy uszkodzeń niż metale. Są one narażone na wszelkie uszkodzenia strukturalne, takie jak pęknięcie żywicy oraz włókien, rozwarstwienia czy nieciągłości struktury. Najczęściej spotykanymi uszkodzeniami materiałów kompozytowych są: rozwarstwienie (delaminacja), utrata sztywności, rozklejenie, pęknięcia (rys. 5.) $\mathrm{i}$ in.

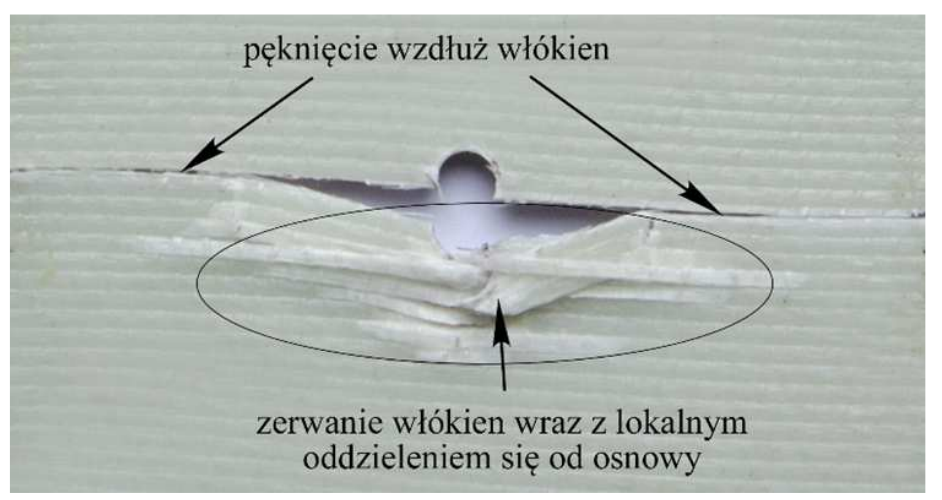

Rys. 5. Uszkodzenie struktury kompozytu włóknistego w okolicy otworu

Fig. 5. Damage of the fiberglass composite structure in the hole area 
Zjawisko delaminacji jest jednym z najpoważniejszych i najczęściej występujących defektów podczas eksploatacji oraz obróbki mechanicznej [11]. Występuje zazwyczaj w kompozytach zbudowanych $\mathrm{z}$ wielu warstw, w następstwach uderzeń i krótkich, gwałtownych przegrzań. Polega na utracie spójności poszczególnych warstw, powodując obniżenie sztywności oraz wytrzymałości materiału.

Kolejnym uszkodzeniem charakterystycznym dla materiałów kompozytowych jest utrata ich sztywności ${ }^{12}$ (rys. 6.), która zależy od właściwości materiałów i konfiguracji struktury (sposobu przyłożenia sił i momentów). W praktyce sztywność struktury określa się za pomocą współczynników sztywności, będących stosunkiem wartości przemieszczenia do wartości siły to przemieszczenie wywołującej [12]. Często towarzyszy jej lokalne rozwarstwienie poszycia, najczęściej spowodowane uderzeniem przez ciało obce (typowe uszkodzenie osłony radaru statku powietrznego przez ptaki). Innym uszkodzeniem kompozytu jest rozklejenie, które jest brakiem lokalnej spójności łączonych elementów kompozytowych. W konstrukcjach lotniczych powstaje ono często w miejscach gromadzenia się wody.

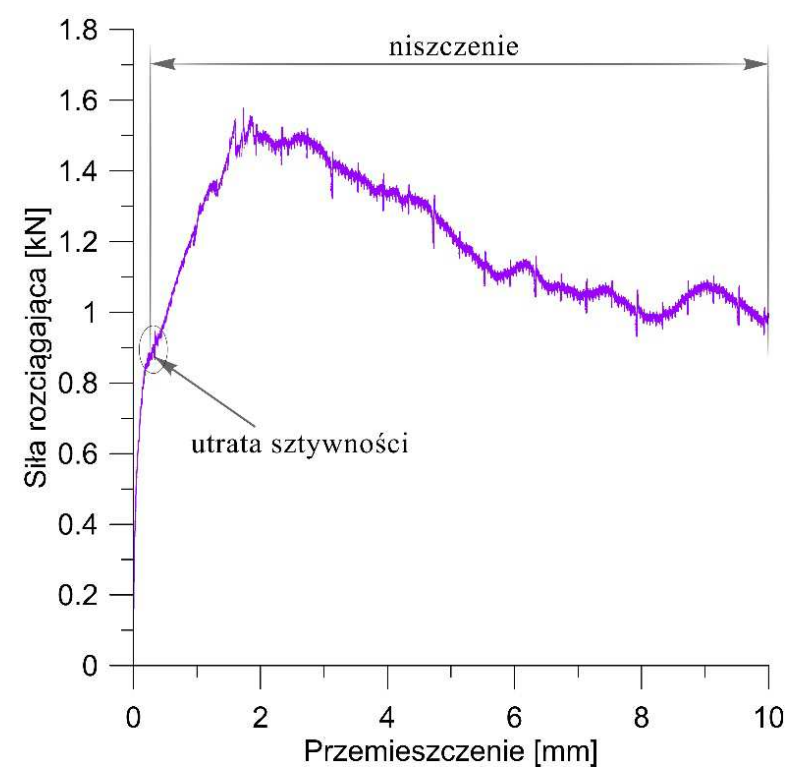

Rys. 6. Wykres zależności siły niszczącej od przemieszczenia w kompozycie włóknistym GFRP podczas próby rozciągania statycznego

Fig. 6. Diagram of destructive force as a function of displacement in GFRP fiber composite during static tensile test

\footnotetext{
${ }^{12}$ Sztywnością jest nazywana zdolność do przeciwstawienia się deformacjom.
} 
Konsekwencje uszkodzeń charakterystycznych zarówno dla metali, jak i kompozytów są bardzo ważne dla konstrukcji lotniczych. Mają one decydujący wpływ na bezpieczeństwo eksploatacji i żywotność samolotu. W chwili obecnej trwają intensywne prace nad modyfikacją składów chemicznych w celu zapobiegania zjawisku korozji. Materiały stosowane w lotnictwie, takie jak tytan, aluminium oraz ich stopy charakteryzują się małą podatnością korozyjną, jednak to zjawisko nadal im towarzyszy. Kompozyty są natomiast tworzywami ulegającymi delaminacji oraz pęknięciom, czasem bardzo silnie propagującym w głąb struktury. Ich wysoka sztywność powoduje tzw. kruche pęknięcia, którym towarzyszy lawinowy wzrost szczeliny prowadzący do zniszczenia elementu [4]. Obecnie dużą wagę przywiązuje się do wykonywania testów za pomocą metody elementów skończonych oraz odpowiedniego oprogramowania ${ }^{13}$ już na etapie projektowania. Pozwalają one na oszacowanie newralgicznych miejsc podatnych na obciążenia oraz występowanie lokalnych bądź globalnych uszkodzeń konstrukcji. Dają możliwość jej wzmocnienia bez nadmiernego wzrostu masy oraz bez zwiększenia użycia materiału.

\section{Podsumowanie}

Dobór materiału ma zasadniczy wpływ na jakość i niezawodność konstrukcji lotniczych, będące podstawowymi czynnikami umożliwiającymi postęp oraz wskazującymi dalsze kierunki rozwoju. Konstrukcje lotnicze mają szczególne wymagania. Poszukuje się materiałów lekkich, a zarazem wytrzymałych mechanicznie i odpornych na korozję. Ważnym aspektem we współczesnym projektowaniu konstrukcji lotniczych jest metoda MES oraz korzystające z niej oprogramowanie. Programy pozwalają małym kosztem określić słabe miejsca konstrukcji, obliczyć żywotność oraz zdatność do użytku sprzętu lotniczego.

Jednym $\mathrm{z}$ kierunków rozwoju materiałów stosowanych w konstrukcjach lotniczych będą niewątpliwie materiały hybrydowe, kompozytowo-metalowe. Okazuje się, że mimo wysokich kosztów ich wytwarzania można uzyskać bardzo korzystne właściwości mechaniczne, a czasem zapobiegać niepożądanym, typowym dla nich efektom. Przykładem jest materiał typu GLARE, który dzięki strukturze aluminiowo-kompozytowej przeciwdziała delaminacji i silne propagującym pęknięciom. W przemyśle lotniczym należy się spodziewać ciągłego współzawodnictwa pomiędzy materiałami metalowymi i kompozytowymi, wyznaczającego tym samym nowy kierunek projektowania materiałów dla lotnictwa. Celem tego przedsięwzięcia jest uzyskanie niższego o 20-30\% ciężaru oraz niższych o $20-40 \%$ kosztów wytwarzania. Cały czas są prowadzone intensywne badania, mające na celu opracowanie nowych materiałów i technologii do zastosowań w lotnictwie, umożliwiających doskonalenie konstrukcji samolotów.

\footnotetext{
${ }^{13}$ Przykładami są programy: ANSYS, NASTRAN, ABAQUS oraz inne.
} 


\section{Literatura}

[1] Dudzik K.: Podatność na korozję naprężeniową złączy spawanych łukowo stopu AW 5059 alustar, Zeszyty Naukowe Akademii Morskiej w Gdyni, 64 (2010), 27-35.

[2] German J.: Interlaminar damage in fiber-reinforced polymeric matrix laminates, Cut, Kraków 2004.

[3] German J.: Podstawy mechaniki kompozytów włóknistych, Politechnika Krakowska, Kraków 1996.

[4] German J., Biel-Gołaska M.: Podstawy i zastosowanie mechaniki pękania w zagadnieniach inżynierskich, Instytut Odlewnictwa, Kraków 2004.

[5] Gibson R.F.: Principles of composite material mechanics, 3rd ed. Boca Raton: CRC Press: Taylor \& Francis Group, 2012.

[6] Gruszczyński E., Błażejewicz T., Stukonis M.: Materiały lotnicze, [w:] Problemy badań i eksploatacji techniki lotniczej, red. J. Lewitowicz, J. Borgoń, W. Ząbkowicz, ITWL, Warszawa 1993.

[7] Jóźwik J., Tofil A., Banaszek M., Kuric I.: Wybrane aspekty obróbki skrawaniem polimerowych kompozytów włóknistych i ocena chropowatości powierzchni, Postępy Nauki Techniki, 15 (2012), 205-220.

[8] Kuczmaszewski J.: Efektywność wytwarzania elementów lotniczych ze stopów aluminium i magnezu, Komputerowo zintegrowane zarządzanie, t. 2, red. R. Knosala, Lublin 2011, s. 7-18.

[9] Lewitowicz J.: Podstawy eksploatacji statków powietrznych. Badania eksploatacyjne statków powietrznych, ITWL, Warszawa 2007.

[10] Mierzwa M.: Wszechstronne zastosowanie tytanu z uwzględnieniem aspektów medycznych, Manag. Systems Production Eng., 4 (12), 2013.

[11] Oczoś K.: Kompozyty włókniste - właściwości, zastosowanie, obróbka ubytkowa, Mechanik, 7 (2008), 579-592.

[12] Wiśniowski W.: Sztywność i utrata sztywności konstrukcji lotniczych, Prace Instytutu Lotnictwa, 214 (2011), 15-23.

[13] Zagrajek T., Krzesiński G., Marek P.: Metoda elementów skończonych w mechanice konstrukcji: Ćwiczenia z zastosowaniem systemu ANSYS, Oficyna Wydawnicza Politechniki Warszawskiej, Warszawa 2006.

[14] www.a350xwb.com (dostęp: 7 lipca 2014 r.).

[15] www.compositesworld.com (dostęp: 7 lipca 2014 r.).

[16] www.jsf.mil (dostęp: 7 lipca 2014 r.).

\section{MODERN MATERIALS USED IN AIRCRAFT CONSTRUCTIONS SELECTED PROBLEMS AND DIRECTIONS FOR DEVELOPMENT}

\section{S u m m a r y}

The article presents the analysis of materials used in modern air structures, with the focus on the structure of the aircrafts airframe. There were presented selected problems concerning the design and operation of aeronautical structures with composites and light metals (aluminum, titanium 
and their alloys). The article is focused on mechanical treatment, such as grinding, making holes and others. The paper describes the problems of analysis of Finite Element Method (FEM), on the basis of two samples made of aluminium alloy and fiberglass composite and the differences between the constructions of these materials and modeling of these material resulting from their different structure (isotropy and anisotropy). The article also includes an analysis of the mechanics of destruction of metal comparing it to composite material. There were presented the trends and the ways of developments of the structural material, including air materials metal-composite. The object of this article is to show modern construction materials used in aerospace structures. The purpose of the publication is to compare the modern construction materials (composites and metals) and to present selected problems in their design and operation of construction. The results of simulation analysis and researches were presented in the content and summary of the article.

Keywords: aircraft structures, composites, light metals, Finite Element Method (FEM)

DOI: $10.7862 / \mathrm{rm} .2015 .20$

Otrzymano/received: 21.11.2014 r.

Zaakceptowano/accepted: $12.03 .2015 \mathrm{r}$. 